\title{
Study on Status Quo and Measures for Intellectual Property Protection in Free Trade Zones
}

\author{
Chuanrong Wang \\ Wuhan University of Science and Technology \\ Wuhan, China
}

\author{
Zuguo Cai \\ Wuhan University of Science and Technology \\ Wuhan, China
}

\begin{abstract}
Economic globalization and regional economic integration are in a rapid development, some new international economic and trade orders have been on the way yet without China's participation. In order to fit international competition in economy, China is trying to find a feasible way for economic development, upgrading the economic growth pattern and creating free trade zones. However, the free trade zones are still a newborn which need to be improved in all aspects, especially intellectual property has been a key point for the economic development. Yet there is still no perfect intellectual property protection system relative to the free trade zones. Therefore, according to analysis of domestic and international situations, status quo and problems of intellectual property protection at free trade zones, this article raises several suggestions for promoting intellectual property protection and system establishment at free trade zones.
\end{abstract}

Keywords-free trade zone; intellectual property protection; status quo and measures

\section{INTRODUCTION}

Accompanied by the acceleration of economic globalization and regional economic integration, new multilateral trade negotiations have made a move for example, developed countries have concluded and released new rules for international trade and intellectual property such as TransPacific Partnership Agreement, Transatlantic Trade and Investment Partnership and Plurilateral Services Agreement, which are expected to replace WTO. In order to deal with negative effects brought by world trade war and reverse the passive economic situation and promote the economic development in the country, on Sep 27, 2013, China (Shanghai) Pilot Free Trade Pilot Zone, the first free trade zone, was approved by the State Council, up to now, 11 free trade zones $(1+3+7)$ have been created in the country. One of the major tasks of the free trade zones is to include China's trade rules and intellectual property systems in the latest world trade laws and rules, so the law and rules in the free trade zones need to be further improved and higher requirements are raised to protect intellectual property in the free trade zones.

\section{Situations OF INTEllectual PROPERTy PROTECTION IN FREE TRADE ZONES}

\section{A. International Situations}

Seen from the current economic development, with the acceleration of economic globalization and technological progress, intellectual property has become a key for an enterprise to gain advantages in competition, especially for a country to win among international competition and predominate around the world, so the intellectual property protection is a necessity for international competition.

Lincoln, the former president of the US ever said that the patent system added the fuel of interest to the fire of genius. The US, a world leading country in science and technology, has set up comparatively perfect intellectual property protection system, besides, relying on the powerful economic forces, it has tried best to upgrade the intellectual property value standards of its own into an international standard over intellectual property affairs around the world. In Japan, intellectual property has been included in national development strategy, with slogans raised successively such as Make the country strong through education, Make the country strong by trades and Make the country by technologies, it has come to know the importance of intellectual property development in a country, so a slogan "Make the country powerful through intellectual property" was raised in 2002, and Outline of Intellectual Property Strategy, as well as Basic Law of Intellectual Property, was issued, and an annual "Intellectual Property Push Program" was released to develop the intellectual property in policies, increase its economic strength and intensify its international competitiveness. South Korea has set a couple of ten-year goals, trying to build itself into a technology leading country, and it has modified domestic policies and improved relevant laws and regulations to safeguard domestic new \& hi-tech enterprises and intellectual property related to foreign affairs. Other countries including Russia and India have also establish intellectual property development strategies, and the intellectual property development protection that all countries value around the world have brought profound influence to international intellectual property protection, and the intellectual property development is in a rapid speed, and the intellectual property development has been a main stream in current stage and even for a long time. Apparently it has become a common strategic selection for developed country to develop technological 
strength, maximize economic benefits and improve international competition through intensifying intellectual property protection.

\section{B. Domestic Situations}

At present, the intellectual property in our country is still in a primary stage, which makes it disadvantageous for our country to solve difficulties and challenges after China's entry to the WTO, among the intellectual property competition around the world, there is an obvious difference in intellectual property between China and developed countries, and the number of patents in developed countries occupy about $90 \%$ of the total around the world. As far as the registered patents, there may be a company which owns about ten thousand trademarks in a developed country, yet the average number of trademarks a company owns in China is less than one, and the development of intellectual property in China still has a long way to go. In fact, such phenomenon is also related to the poor awareness of intellectual property of the people, which have callused that most famous trademarks at home are taken over in foreign countries, and the place of origin fails to be well protected.

Since China's opening up and reforms, the country has entered a deep-water area and difficult stage in reform, and the economic development is in a crucial stage of transformation and adjustment, Shanghai Free Trade Zone is a pilot area selected in the country for new pilot, which aims to speed up the reform through opening up so as to adapt to the great changes of global economy. Facing the aggressive situation from western countries, our country has been making the intellectual property protection denounced and been isolated in a new round of multilateral trade negotiations, in an attempt to exclude the new economic systems established in China. One of the important goals of free trade zones is to integrate China's rules of trade service and intellectual property to the rules of world trade systems so as to take the initiative in world trades, perfect laws and systems of trade service and intellectual property in the country and avoid being put aside.

\section{StATUS QUO AND PROBLEMS ON INTELLECTUAL Property PRotection AT FreE TRADE ZONES}

\section{A. Status Quo of Intellectual Property Protection}

In the 17th CPC National Congress, then-president $\mathrm{Hu}$ Jintao proposed that China must improve its capabilities of independent innovation, build an innovative type country and carry out an intellectual property strategy. On Jun 5, 2008, national intellectual property strategy was issued, clearing upgrading the intellectual property to a national strategy. The free trade zone, a test land for economic structure transformation, also highlights the intellectual property protection, especially the establishment and development of Shanghai Free Trade Zone has provided experience for the construction and improvement of other free trade zones.

1) Gradually establish and perfect a judicial protection system for intellectual property: Before construction of the free trade zone, in order to promote the intellectual property, Shanghai took the lead to issue the Outline of Shanghai
Intellectual Property Strategy (2011-2020) in 2012, where an eight-year plan was established to build Shanghai into an Asian Pacific Region Intellectual Property Center featuring "Innovative factors gathered, complete protective systems, perfect service systems and top quality talents collected" by 2020. In order to achieve the goal, after incorporation of Shanghai Free Trade Zone, it has further strengthened judicial protection.

In 2013, the first intellectual property court for free trade zone was established in Shanghai, according to the position and characters of innovative reforms in the zone, the court is focused on civil and commercial cases related to the zone, mainly including the zone-related investment, commerce, finance, intellectual property and real estate cases, which are being adjusted as well as per the zone construction and practice. In 2014, an intellectual property court was set up in Shanghai, which governs civil and administrative cases related the intellectual property in the first instance, and will be built gradually into an important support for technical innovation with global influence. In 2015, in order to further intensify the intellectual property protection, adapt to new conditions in the free trade zone and solve new problems arising in the zone, a Supreme People's Court Free Trade Zone Intellectual Property Judicial Protection Investigation and Contact Station was set up, which was another important action to secure the free trade zone through judicial service. The measures adopted form a "Pudong Pattern", realizing the whole inclusion of three in one of intellectual property trial.

Intellectual property courts are set up in many free trade zones, and intellectual property trial teams which are new type, highly professional and adaptable are organized, which help promote the intellectual property trial jurisdiction to keep centralized, intensive and professional. Some of free trade zones set up "Internet intellectual property judicial protection service station", appoint special workers, make rules and systems in order to solve difficulties enterprises get involved in intellectual property protection. In the meantime, in order to introduce high quality professional talents and supply bloods to the intellectual property trial teams, some cooperate with colleges to build "free trade zone intellectual property teaching practice base", organize personnel to study and discussion and keep improving the judicial theory levels of intellectual property. In addition, academicians from Chinese Academy of Sciences and Chinese Academy of Engineering and so on are invited as special technical experts and intellectual property experts, and intellectual property experts and scholars are appointed as expert jurors, and first technical investigators are invited for technical support.

2) Improve and perfect the free trade zone intellectual property enforcement mechanism: Though for a long time, the administrative protection on intellection property is much mature than judicial protection, yet due to the strengthening of judicial protection, the two-system protections have caused conflicts between protective standards and enforcement and difficulty to integration. In order to solve the problem, in Sep 2014, China (Shanghai) Free Trade Zone Management Committee Intellectual Property Bureau was established, which marked a new stage of administrative protection and 
management on intellectual property, starting a new chapter for the intellectual property career in the city, which made an important step in establishing a uniform intellectual property administration and enforcement mechanism. The Bureau is an independent player in organization, undertaking intellectual property administration and enforcement, which was the first in the country. During the enforcement, relevant departments are promoted for joint actions, offices of different authorities have settled in the free trade zone, making it easier for administrative enforcement.

In addition, new changes have happened in enforcement by customs, 14 new free trade zone customs supervision service innovation systems are released such as "Allow to enter the zone before declaration", which simplifies inventory systems. Besides, the Shanghai Free Trade Zone Rules emphasize the enterprise credit system construction, strengthen the enterprise credit management, and promote its integration to social credit systems so as to jointly build an enterprise intellectual property credit system and guide and regulate enterprise operation and management.

3) Much advanced intellectual property achievements: Shanghai is a great city leading in intellectual property protection in the country, ahead of others across the country, in 2004, Shanghai took the lead to issue the Outline of Shanghai Intellectual Property Strategy (2004-2010), pointing out that Shanghai should be built into an Asian Pacific intellectual property center. After a string of efforts and measures, the investigations on intellectual property show, the number of application for patents for invention and patent licensing is increased greatly, yet the number of application for design patents is reduced sharply, which turns out that the intellectual property results turn to a top level.

\section{B. Problems on Intellectual Property Protection at Free Trade Zones}

As a pilot reform zone, the free trade zone is still in a test stage, which has brought some successful experience and also exposed some problems in intellectual property, since each region has characteristics of its own in development, the problems exposed diverse as well, here the author just gives some of typical ones.

1) Inconsistence between law of intellectual property and construction of free trade zones: The establishment of free trade zone has raised China's opening up to a new level, and it is more closely internationalized, meanwhile, many new problems have risen, the internal lagging in law and actual characters of the free trade zone have caused that existing laws and regulations are far to meet the need of free trade zones.

With reward to judicature, due to higher opening, diverse commercial trade and frequent trades in the free trade zone, there exist a great number of infringements of intellectual property, most get involved in higher amount of funds. When such cases are handled, they are not classified in amount, and there are special procedures designed for low-amount cases, and all cases are treated without differences, which make it complicated for case handling, in addition, due to lower amount and obligees' failure to cooperate, it is a little difficult to obtain evidences, lowering the judicial efficiency and going against the logical allocation of judicial resources. With regard to administration, procedures of administrative examination and approval are much more complicated, for affairs related to repeated examination and able to agreed freely by the those concerned may have examination and approval procedures simplified or removed. On customs enforcement, the over simplified procedures for custom clearance and supervision may cause more infringements in free trade zones, and it will be more difficult to fight infringements, for example, if there is no supervision on single goods process in free trade zones, some illegal dealers may make use of the loophole to process counterfeits, with fake brands and packing, the goods will be sold across the country or exported to other countries around the world.

2) Loose relations between functional departments, late in sharing information: The highly advanced information technologies have made it easier for governmental administration and judicial practice, improving the judicial efficiency. However, currently all sectors are closely connected and information pass and sharing can be achieved rapidly, causing a situation where every sector does things of its own. The issue of intellectual property is more than what a functional department can do, which get widely involved, needing joint treatment by several departments, and information blocks exist between sectors, which are barriers for solving intellectual property problems and setting up intellectual property mechanism.

3) Enterprises' poor awareness of intellectual property protection, lack of sound air of intellectual property protection: At present, there are numerous medium, small and micro enterprises in free trade zones in the country, which have little understanding of intellectual property, even some never get involved intellectual property operations or disputes, or patent technology transfer for import around the world. Due to little understanding of intellectual property and poor awareness of relevant laws and regulations, many enterprises which engage in goods import and export in free trade zones generally are in higher risks than common enterprises. Some enterprise which own intellectual property are only in stage of number accumulation, winning national awards and evaluation, yet all almost have no thought of operating intellectual property.

4) No enthusiasm in intellectual property development and lack of incentive innovation mechanism: The intellectual property development is a drive to economic development, yet many enterprises even authorities in free trade zones have no deep understanding of this point, and no special attentions are paid to supporting and safeguarding intellectual property, some free trade zones are newly established, some preferential and incentive policies are still not released, which cause that the enterprises in free trade zones enjoy no more advantages from the further opening up, and the operation and protection of intellectual property are only kept on papers. Medium, 
small and micro enterprises have no adequate funds or intellectual property management talents, besides, the costs for applying for international patents are higher and more difficult, which make them do more in thought than action, with no benefits support and lack of adequate costs, no enterprises show enthusiasm or confidence to intellectual property development, causing the abortion and difficult labor of intellectual property results.

\section{MEASURES AND SUGgESTIONS FOR INTELLECTUAL PROPERTY PROTECTION IN FREE TRADE ZONES}

The intellectual property economic growth in free trade zones raisers higher requirements on the intellectual property protection, based on the status quo and problems regarding intellectual property protection in free trade zones and situations at home and abroad, this author raises several suggestions listed as below.

\section{A. Improve the Intellectual Property Protection Mechanism and the Multiple Protection Mechanism}

Free trade zones are a part of China' territory, relevant handling of intellectual property shall comply with laws and regulations regarding intellectual property in China, however, as far as international treaties, different regions and judges will make different explanations on the treaties, causing confusion in law application, so they are still in transformation to apply. Therefore, it needs to clarify in law and transform in advance, providing convenience for application of international treaties, unify standards for explanations and regulate the application in law.

Considering that there are numerous intellectual property cases in free trade zones, besides, most cases get involved in small amount and diversity, we should consider a multiple dispute settlement mechanism, in addition to judicial protection and administrative projection, we can introduce multiple solutions such as mediation, reconciliation, arbitration and so on, and rapid and simple procedures can be adopted on small-amount cases; and highly efficient solutions such mediation and arbitration can be adopted for small-amount disputes, with the thought of those concerned fully considered. Due to the foreign involvement in free trade zones, we can borrow foreign professional arbitration organs in order to make the cases solved with convenience, efficiency and satisfaction.

With regard to administrative enforcement pattern, generally there are professional intellectual property enforcement agencies in free trade zones, where cross management is carried out. In order to improve the work efficiency of enforcement agencies, it needs to set up perfect and uniform intellectual property enforcement agencies as soon as possible. And the supervision in free trade zones shall adopt "Free for first tier and Strict in second tier" principle. Currently there are no clear rules about custom administrative enforcement, in order to prevent the free flow of infringing goods in free trade zones, the lowest standard related to international treaties shall be carried out at first-tie pass for strict control.

\section{B. Perfect Intellectual Property Management Mechanism and Share Information among Departments}

There are numerous and complicated information about intellectual property, it needs to clarify duties for all managements, and the information related to intellectual property such as registration, filing, keeping, use and transfer shall be uniformly managed; create information systems and set up online information sharing platforms, get information about intellectual property through electronic data, making it easy for functional departments for management, collaboration, reduce enforcement costs, conduct overall analysis on data, deeply dig, adopt measures as the case may be and make policies as required.

\section{Strengthen Awareness of Intellectual Property and Crate Sound Air for Intellectual Property Protection in Enterprises}

With the technical development, intellectual property development has become a significant premise for market competition, and the quality and number of intellectual property has become one of key indices to weigh the integrated competitiveness of a country, to understand and grasp knowledge about intellectual property can not only protect the rights of our own but also protect our rights from being infringed, so more knowledge about intellectual property should be promoted to enterprises, more chances shall be provided or enterprises shall adopt targeted training. For most businesses in free trade zones get involved foreign trade, especially it needs to understand and master international treaties about intellectual property protection. Renew thoughts and ideas, change the past improper doings such as valuing results only, stressing theories only but ignoring economic benefits, and set up a development thought of shaping and economizing the intellectual property.

\section{Establish Incentive Policies and Fully Stir the Enthusiasm for Technical Innovation}

Technical innovation needs better policy support, it needs to issue human oriented policies, activate human capitals and produce joint effects through technical innovation. Set up intellectual property protection special fund, promote to economize results, solve the dilemma enterprises face just like "One cannot make bricks without straw", especially more supports shall be given to invention patents needing higher technical conditions. In addition, create a white list for intellectual property related enterprises, to which preferential policies such as credit loans and government subsidies will be given, based on supervisions over the enterprises on the white list, we can have the suitable enterprises survive and develop and reject the unsuitable ones and keep enterprises going under supervisions. Besides, establish intellectual property talent mechanism, attracting those excellent to the free trade zones, improve the intellectual property level as a whole and promote the technical innovation.

\section{CONCLUSION}

The establishment of free trade zones is a necessary attempt for the country to achieve the economic transformation 
and include it in the world market. With the deep development of economic globalization, all countries especially west developed countries conclude some "partnership" international treaties yet excluding China, trying to seize free trade markets around the world. Facing such unfair market economy trend, China is urgently needed to carry out an intellectual property innovative development strategy, building China into a powerful country in intellectual property, raising the speaking right of China in forming intellectual property rules around the world and include China's intellectual property rules in the world trade service and intellectual property systems, therefore, it is becoming extremely important to perfect the intellectual property protection mechanism in free trade zones. To efficiently protect the intellectual property of holders at home and abroad can make it better to introduce what advanced but others hold and internationalize what we have so as to improve the integrated competitiveness of our country in the trend of economic globalization and make our country great around the world.

\section{REFERENCES}

[1] Wu Handong, Suo Fushou, Concept and Policy of Judicial Protection over Intellectual Property in China [J]. Contemporary Law Review, 2013(6).

[2] Zhang Weijun, Enforcement of Intellectual Property in Shanghai Pilot Free Trade Zone: Balance between Free Trade and Fighting Infringement [J]. Foreign Economies and Management, 2014.

[3] Li Xuehui, Appellate Court for Intellectual Property: Borrowing and Enlightenment [J]. New Angle of Uiew, 2005.

[4] Song Xiaoming, Judicial Policy Regarding Intellectual Property under a New Trend in China [N]. People's Court Daily, 2015-4-23.

[5] Guo Xiujuan, Discussion on Intellectual Property Systems in China [J]. Science \& Technology Information, 2014(29).

[6] Cong Lixian, Influences of Trans-Pacific Partnership Agreement Intellectual Property Negotiations on China and Countermeasures [J].2014.

[7] Zheng Chengsi, Selected Works of Zheng Chengsi [M]. Beijing: Law Press, 2003.

[8] Jiang Zhipei, Study on Intellectual Property Protection by Law After China's Entry to the WTO [M]. Beijing: China Renmin University Press.

[9] Li Xuehui, Appellate Court for Intellectual Property: Borrowing and Enlightenment [J]. New Angle of Uiew, 2005. 